\title{
Entrepreneurship Education Curriculum Design of College Student Based on the Perspective of Business Model
}

\author{
Yang Si \\ College of Economics and Management \\ Qujing Normal University \\ Qujing, China
}

\begin{abstract}
Entrepreneurship education is needed to improve college student's entrepreneurial ability, and it could be upgraded by entrepreneurship education curriculum design of college student based on the perspective of business model. This paper analyzes the relationship between business model and entrepreneurship of college student, points out the necessity of carrying out entrepreneurship education curriculum which is based on business model, and then discuss the design of this sort of curriculum.
\end{abstract}

Keywords-curriculum design; entrepreneurship education; business model

\section{INTRODUCTION}

Under the historical background with the economic transformation and upgrading in China, the economic development that takes market and innovation as the core driving forces has promoted the entrepreneurship to a new strategic height. The entrepreneurship is profoundly influencing and changing the economy of China and the life of Chinese people. Under the stimulation of "mass entrepreneurship and innovation", increasing numbers of college students devote to the entrepreneurship to pursue their entrepreneurship dream. At the meantime, with the rising of the "Internet Plus", tremendous pioneering enterprises emerge and use the new business model to overturn the traditional industries. Just as Peter F. Druker says, today's enterprise competition is the competition on the basis of the business model. The continuous innovation of the business model is changing the pattern of the market competition, and has created new opportunities for the entrepreneurship of college students. However, at present, the importance of the business model has not been highlighted in the entrepreneurship education of colleges. Besides, there is not the complete course design. In practice, the course design that centers on the business model in the entrepreneurship education succeeds in better cultivating the creative spirit and the entrepreneurial ability of college students. According to the relation between the business model and the entrepreneurship of college students, this paper discusses on the necessity of the entrepreneurship education on the basis of the business model and how to carry out the course design of the entrepreneurship.

\section{THE BUSINESS MODEL AND THE ENTREPRENEURSHIP OF COLLEGE STUDENTS}

\section{A. The Business Model}

The business model is a concept of development. Researches on connotations of the business model have experienced four stages. With the expansion of the research perspective, the economic view based on profit taking, the operation concept based on the process and the structure inside enterprises and the strategic view based on the selection of the business direction and the acquisition of competitive advantages, as well as the integration concept that combines the former three have formed. [1] Broadly speaking, the business model is the process that the enterprises surround target customers to create, transfer and acquire values [2], and the basic frame for the survival and the development of enterprises. The business model contains multiple factors, including the target customers, the customer relations, the value proposition, the key resources, the critical activities, the channels, the key operation, and the source of income as well as the cost structure [2]. The factors form the business model through interaction and combination. Meanwhile, they influence the competitive advantages and the earning power of the enterprises. With the changes of internal and external environment of the enterprises, enterprise management level can adjust the combination of the factors in the business model through judging the situation, in order to keep the competitive advantages. The change of any factor in the business model will lead to the reconstruction and the innovation of the business model, and then change the competitive ability of the enterprises. It embodies the business model is innovative, systematic, dynamic and competitive.

\section{B. The Entrepreneurship of College Students and the Business Model}

As the temporary organization that pursues growth and the profit model, the pioneering enterprises need to develop, implement and adjust the business model to achieve the organization goal [3]. The combination between the entrepreneurship of college students and the business model has internal logic. First, the design of the business model is the 
frontier research field in the business circles and is the highly creative planning work. College students are pleased to learn and practice. College students have advantages in entrepreneurship because they have relatively high degree of education, active mind and entrepreneurial passion. It makes college students have strong ability to learn and accept new technology, new things and new model. Second, the business model helps college students to implement the high quality entrepreneurial activities through using the limited resources and technology. College students have disadvantages in the entrepreneurship, because they lack entrepreneurship resources and experience. Besides, they have poor risk resistance capacity. Therefore, when choosing entrepreneurship programs, college students prefer to the industry with the relatively low admittance threshold and the fierce competition. The innovation of the business model enables college students to open up the undiscovered market space, transforming "small business" into "big business".

\section{THE NECESSITY TO PROVIDE THE ENTREPRENEURSHIP COURSES BASED ON THE BUSINESS MODEL}

As the main battlefield to train the entrepreneurial talents, colleges must keep pace with the times in the entrepreneurship education and timely bring the business model in the course design at the same time implement it as the key teaching points. The problems in the course design of the entrepreneurship education and the advantages in implementing the entrepreneurship courses on the basis of the business model are elaborated as follows.

\section{A. The Problems in the Course Design of the Entrepreneurship Education at Present}

At present, the entrepreneurship education in the colleges has the following problems: First, the course design of the existing entrepreneurship education centers on teaching the entrepreneurial knowledge. It is difficult to embody the educational goal of improving the entrepreneurial thoughts and ability of college students. Second, the entrepreneurship education teaches the knowledge of different disciplines and pays no attentions to the relationship of the knowledge between different disciplines. The contents are separable, so that the students make thorough analysis in solving the problems in the entrepreneurship but fail to find the systematic solutions. Third, majority of the existing entrepreneurship education centers on the "good idea" or "good products", lacks the ability to build the operation system that takes customer demand as the orientation. It makes the creativity become the theory and cannot turn it into results. Finally, the courses of the existing entrepreneurship education attach importance to the compilation of entrepreneurial project plan, neglect uncertainties and dynamism in the entrepreneurial process, leading to misunderstandings of the students. They think the entrepreneurial project plan compiled elaborately is the guarantee of the successful entrepreneurship. Therefore, the risks of the blind entrepreneurship increase.

\section{B. The Necessity to Provide the Entrepreneurship Courses on the Basis of the Business Model}

To supplement and upgrade the traditional entrepreneurship education, emphasizing the importance of the business model and providing the entrepreneurship courses on the basis of the business model can break through the limitation of the traditional entrepreneurship education. The entrepreneurship courses on the basis of the business model have the following advantages.

1) Develop the more comprehensive and more systematic entrepreneurial perspectives of college students: In the traditional concept, the technological entrepreneurship that centers on the development of new products restricts the entrepreneurial perspectives of college students. On one hand, it makes many college students who are not majors of science and technology shrink back at the sight of the entrepreneurship because of technical threshold; on the other hand, it makes the entrepreneurs that consist of college students who have a perfect mastery of technology neglect the market demands. Market demands are the very foundation for the survival and the development of the entrepreneurship. The entrepreneurship courses with business model make college students no longer focus on the products or the inside of enterprises. They will treat the entrepreneurship from the systematic entrepreneurial perspectives and think about the problems in the entrepreneurship.

2) Train entrepreneurial thoughts of college students: In some sense, the innovation of the business model is more extensive than the technological innovation. First, the economic value of the technological innovation depends on the business model; second, even though the technological level is not changed, changing elements of the business model or adjusting the combination of the elements can achieve the enterprise innovation [4]. For example, in the "Internet Plus" traditional industry, numerous innovations are the innovation of the business model, but it does not change the original production technology. Entrepreneurs of college students can start from the innovation of the business model, consider how to design the new business model under the existing conditions to better create values and transfer value for the customers. Although some students have not implement entrepreneurial activities, the design of the business model helps to train their innovation and entrepreneurial thoughts.

3) Improve the entrepreneurial ability of college students: The ever-changing business environment increases the uncertainties of the entrepreneurship. College students have difficulties in formulating a "perfect business plan" at the beginning of entrepreneurship and implementing it. Entrepreneurs of college students must review the entrepreneurship from the perspective of the dynamic development. At the meantime, they must continuously improve the business model according to the model of "design, trial implementation, adjustment, try-out anew", in order to deal with the changes of the entrepreneurial environment. It transforms the static planning model of the traditional 
entrepreneurship education into the dynamic practice model. College students continuously think and practice in the entrepreneurial process and improve the entrepreneurial ability in the ceaseless trial and adjustment.

\section{THE DESIGN OF THE ENTREPRENEURSHIP COURSES ON THE BASIS OF THE BUSINESS MODEL}

The course design is to "plan and arrange aspects of the courses". This paper will discuss the design of entrepreneurship courses on the basis of the business model from four aspects, including the course objectives, the course contents, the course structure and the course evaluation.

\section{A. The Course Objectives}

When setting the course objectives, the objective orientation of the entrepreneurship education and the orientation of the entrepreneurship courses should be considered roundly. According to the objective orientation of the entrepreneurship education, the entrepreneurship education in the colleges is to train innovative talents and to improve their entrepreneurial spirit and ability [5]. It is the fundamental guidance and the ultimate purpose of opening entrepreneurship courses. The objective in the design of entrepreneurship courses should subject to the fundamental goal. According to the orientation of the entrepreneurship courses on the basis of the business model, because the business model is the top-level design of pioneering enterprises and is the core frame that covers the enterprise operation, the knowledge of multiple disciplines including strategy, operation and finance must be integrated in the design. Therefore, the course is the core course based on the courses of the entrepreneurship education. Compared with the courses like the entrepreneurship basis, it pays more attentions to the cultivation of the entrepreneurial thoughts and the entrepreneurial ability.

According to the above-mentioned training objective and the course orientation, the specific objectives of the entrepreneurship course will be formulated from four aspects, including knowledge, ability, emotion and practice [6]. First, the knowledge objective includes the concept of the business model and the components. Second, the ability objective requires students to grasp the analysis model of the business model, analyze, conceive, reconstruct and innovate the business model according to the specific entrepreneurial environment. Third, the emotion objective aims at stimulating the interests of students in entrepreneurship, letting students feel the unique value and charm of the business model. Students learn to appreciate the business model with skillful conception and become more yearning for the entrepreneurship. Fourth, the practice objective is to let students acquire more abundant direct experience through the entrepreneurial activities. They internalize it into the entrepreneurial ability and then improve entrepreneurial behaviors.

\section{B. The Course Contents}

The following elements are considered in the selection of the contents of the entrepreneurship courses: First, conform to the course objectives; second, reflect the frontier research results; third, it must be concise and profound and suitable for college students to learn; fourth, it can go through the practice test and can solve practical problems; fifth, it must have abundant matched teaching resources.

After the comparison and the analysis, the teaching contents of the course take "the structure of the business model with six elements of Wei and Zhu" proposed by professors Wei Wei and Zhu Wuxiang as the theoretical basis of the courses. Meanwhile, the course contents are built according to the theories and the cases of the business model under the entrepreneurial environment. "The structure of the business model with six elements of Wei and Zhu" is the theoretical frame summarized through researches on tremendous cases at home and abroad. It is helpful for the analysis and the design of the business model. Besides, the model is concise and beautiful and can grasp the core elements of the business model and their relations, so students can learn and grasp more easily. At the meantime, the model is widely applied to numerous consulting projects. It experiences the inspection of the business practice and can provide practice guidance. There are abundant books related to the model of the business model. For example, the books such as To Discover the Business Model, To Reconstruct the Business Model and the Economic Explanation of the Business Model written by the two professors jointly can be taken as the reference materials in teaching. The two professors address the business model is "the structure of deal between the enterprises and its stakeholders". The structure of the business model with the six elements starts from the orientation element and builds the operation mechanism that contains four interrelated elements such as business system, key resource capability, profit model and cash flow structure, in order to create the final element of the enterprise value [4]. The contents of the entrepreneurship courses are built on the model. Each element of the business model mentioned above constitutes a teaching module. There are eight teaching modules in total after the integration teaching module and the teaching module of the comprehensive practical training are counted in.

\section{The Teaching Strategies of the Courses}

The teaching strategies of the courses are mainly planned and implemented from three aspects, including optimizing the teaching staff, innovating in the teaching methods and strengthening the practical teaching.

First, we must optimize the teaching staff and improve the quality of the entrepreneurship education. High quality teachers are the foundation and the guarantee of the entrepreneurship education. It is necessary to train professional teachers for the entrepreneurship education. However, the entrepreneurship education still belongs to new things at home and is at the exploratory stage. Majority of teachers of the existing entrepreneurship education are teachers of related disciplines and the administrative staff of employment. The deficiency of professional entrepreneurship mentors has become one of the bottlenecks in the entrepreneurship education. In order to improve the level of the entrepreneurship education, we must optimize the teaching staff and build the teaching team in which the teachers complement advantages of each other. Furthermore, we must integrate teachers who teach knowledge, provide practice 
guidance and cultivate comprehensively, promote the operation of industry, college and research [5], and improve the level of the teaching team through training and part-time job in the enterprises.

Second, we must innovate in the teaching methods to improve the entrepreneurial thoughts and ability of college students. The entrepreneurship is an innovative social practice. The entrepreneurial quality of entrepreneurs is core competitiveness. Therefore, the teaching must highlight the ability orientation and center on the students and let them play the dominant role. The entrepreneurship courses on the basis of the business model center on the project teaching method. The teaching methods such as expository method, case teaching and role play are used in the teaching. The teaching methods are used according to the different teaching objectives and situations. The project teaching method is used to guide students to complete the design project of the business model. It requires students to design a complete business model in groups for a entrepreneurship program, in order to train the entrepreneurial thoughts and the planning ability; the expository method explains the key points, the difficult points and fallible points of the courses; the method of the case teaching develops thoughts of students and enlightens their creative thinking; the method of role play creates the practice environment and guides students to implement transpositional consideration. The comprehensive teaching methods enable the students to achieve the results of designing the business model after the end of the courses, and let them deepen the entrepreneurial experience in the teaching process and improve the entrepreneurial ability.

Finally, we must strengthen the practical teaching and build comprehensive practice platform. The entrepreneurship education must implement the thought of combining theory with practice and embody it in the practice. In the practical teaching, teachers must integrate the resources in and after class, the online and offline resources and the resources on and off campus. At the meantime, they must carry out diversified practical teaching through the combination of classroom training, laboratory, entrepreneurial competition, club activity, innovation park of college students and training base in the enterprises. The importance of the practical teaching is highlighted because the business model develops with the change of the commercial environment and needs reconstruction, and students cannot grasp its essence in the classroom teaching with limited time. The practical teaching is the continuity and the sublimation of the classroom education, especially the extracurricular practice of operation between school and enterprise. Students can get direct experience and carry out long-term tracking and learning. This process improves the ability to build and reconstruct the entrepreneurial business model.

\section{The Course Evaluation}

The course evaluation bases on the completion of the course objectives and its effects. The sound evaluation system can find problems in the courses and pertinently improve it. The evaluation of entrepreneurship courses on the basis of the business model adopts three ways of comprehensive evaluation: First, investigate and evaluate different stages on the basis of the complete period of course teaching. Check and evaluate timely after the teaching module is completed; second, the evaluation must take the improvement of the entrepreneurial thoughts and the entrepreneurial ability of students as the value orientation; third, multiple evaluation subjects participate in the course evaluation through the college evaluation, the evaluation of cooperators, the evaluation of experts and the evaluation of students as well as the evaluation of teachers, in order to obtain abundant information for improvement of the course design and improve the quality of the course design.

\section{CONCLUSION}

The construction and the innovation of the business model are necessary skills of the college students in the entrepreneurship. The course design of the entrepreneurship on the basis of the business model is to upgrade the basic entrepreneurship education. The entrepreneurs that consist of the college students can improve innovation and entrepreneurship capacity through learning and practicing the business model. This paper discusses the course design of the entrepreneurship that bases on the business model from four aspects, including the course objectives, the course contents, the teaching strategies and the course evaluation.

\section{REFERENCES}

[1] Yuan Lei. Evaluation on Theoretical Research of Business Model at Abroad [J], Foreign Economics and Management, 2007(10)

[2] Alexander Osterwalder, Yves Pigneur, Business Model Generation [M], China Machine Press, 2011

[3] Yu Lexin, Xue Hongzhi, Yang Jun. Research Review of the Business Model Adjustment for Pioneering Enterprise and the Prospects [J], Foreign Economics and Management, 2013(11)

[4] Wei Wei, Zhu Wuxiang. To Discover the Business Model [J], China Machine Press, 2009

[5] Yang Xiaohui. Research on the Entrepreneurship Education in Chinese Colleges and the Training of Innovative Talents [J], China Higher Education Research, 2015(01)

[6] Xie Shuping. Thinking on the Course Design in the Entrepreneurship Education and the Implementation $[\mathrm{J}]$, Vocational and Technical Education, 2002(7) 